\title{
Media Pembelajaran Virus Influenza Berbasis Flash
}

\author{
Nurseba Dantri L \\ IIK STRADA Indonesia \\ Email: nursebadl@gmail.com
}

\begin{abstract}
Abstrak
Influenza(flu), merupakan penyakit menular yang disebabkan oleh virus RNA dari familia Orthomyxoviridae (virus influenza), yang menyerang mamalia dan unggas. Gejala paling umum penyakit ini adalah demam, nyeri kepala berat, nyeri tenggorokan, menggigil, nyeri otot, batuk, kelemahan, dan rasa tidak nyaman secara umum. Infeksi saluran nafas akut merupakan pencetus utama terjadinya asma eksaserbasi akut. Salah satu penyebab dari infeksi saluran nafas tersebut adalah virus influenza. Tujuan dari telaah kasus adalah untuk mengetahui sejauh mana efektivitas penggunaan media pembelajaran berbasis flash dalam pencegahan influenza. Pelajaran virus infuenza merupakan topik yang menarik untuk dipelajari. Salah satu cara untuk memahaminya adalah melalui media pembelajaran virus influenza. Pencarian dilakukan pada database Neliti. untuk mengidentifikasi artikel yang relevan. Pencarian dilakukan pada tanggal 25 Desember 2019. Terdapat dua artikel yang memenuhi kriteria dan dapat diakses secara penuh untuk digunakan dan dilakukan telaah kritis.
\end{abstract}

Kata kunci : Asma, Media Pembelajaran Virus Influenza Berbasis Flash.

\section{Latar Belakang}

Di Indonesia, prevalensi asma pada tahun 2013 sebesar 4,5\%, lebih tinggi dibandingkan penyakit lain seperti Penyakit Paru Obstruktif Kronik (PPOK) dan kanker. Sebesar 60\% asma eksaserbasi akut disebabkan oleh infeksi saluran nafas atas akibat virus, contohnya virus influenza. Virus tersebut merusak epitel saluran nafas dan menimbulkan respon inflamasi yang dapat mengobstruksi jalan nafas. Selain dapat mencetuskan asma eksaserbasi akut, virus influenza juga menjadi faktor risiko memberatnya infeksi saluran nafas bawah.

Pada masa ini, masih kurangnya tingkat kepedulian masyarakat Indonesia terhadap penyakit influenza. Penyakit ini juga seringkali dianggap remeh oleh masyarakat indonesia. Padahal virus influensa dapat berevolusi menjadi penyakit yang mematikan dan mebahayakan. Hal ini sangat mengkhawatirkan, maka dari itu agar masyarakat dapat mengetahui lebih jelas mengenai virus influenza. Akan dibuat sebuah media pembelajaran yang menarik dan mudah untuk dipelajari.

Beberapa penelitian membuktikan bahwa penggunaan multimedia dalam pembelajaran menunjang efektivitas dan efisiensi proses pembelajaran. Flash merupakan salah satu teknologi komputasi multimedia. Multimedia dapat diartikan sebagai kombinasi dari grafik, teks, animasi video dan suara yang digabung menjadi satu kesatuan kerja yang menghasilkan suatu informasi yang memiliki nilai komunikasi interaktif yang sangat tinggi. Adobe Flash sebagai media 
pembelajaran di kemas dalam perpaduan satu kesatuan kerja dan yang digunakan untuk menyampaikan materi. Dengan keungulan ini diharapkan memudahkan pengguna dalam mempelajari virus influenza.

\section{Kasus/Masalah}

a) Tingginya kejadian asma akut akibat influenza

b) Bagaimanakah efektivitas media pembelajaran virus influenza berbasis flash ?

\section{Tinjauan Pustaka}

\subsection{Influenza}

Influenza, yang juga dikenal dengan sebutan flu, merupakan penyakit menular yang disebabkan oleh virus RNA dari familia Orthomyxoviridae (virus influenza), yang menyerang mamalia dan unggas. Gejala yang paling umum dari penyakit ini adalah sulit menelan, batuk, menggigil, demam, nyeri kepala berat, nyeri tenggorokan, nyeri otot, kelemahan, dan rasa tidak nyaman secara umum.

Bila gejala menganggu dapat digunakan obat dekongestan nasal/pelega hidung. Obat simpatomimetik adalah pilihan untuk dekongestan nasal. Dekongestan nasal dapat berupa obat oral dan spray. (Puspitasari, 2010)

Dalam kasus lebih serius, influenza menyebabkan radang paru-paru, yang dapat menimbulkan kematian. Biasanya, influenza ditularkan melalui udara oleh bersin ataupun batuk, yang membuat udara di sekitarnya mengandung virus Influenza. Influenza juga dapat ditularkan melalui air liur, kotoran burung, nasal secretions (ingus), kotoran dan darah. Infeksi juga terjadi melalui kontak dengan cairan tubuh. Virus influenza dapat menjadi tidak aktif/mati oleh sinar matahari, disinfectan dan deterjen. Virus dapat juga dibunuh oleh sabun, sering mencuci tangan dapat mengurangi risiko terjadinya infeksi.

\subsubsection{Jenis virus influenza}

Dalam klasifikasi virus, virus influenza adalah suatu virus RNA keluarga Orthomyxoviridae, yang terdiri dari tiga genera:
a. Influenza virus A
b. Influenza virus B
c. Influenza virus $\mathrm{C}$

Virus-virus ini terkait dekat dengan virus parainfluenza manusia, dimana virus-virus RNA termasuk dalam keluarga paramyxovirus yang umum menyebabkan infeksi pernafasan pada anak-anak namun juga dapat menyebabkan penyakit yang serupa dengan influenza pada orang dewasa.

\subsubsection{Influenza virus A}

Genus ini memiliki satu spesies yaitu virus influenza A. Burung perairan liar di alam bebas menjadi rumah bagi berbagai variasi influenza A. Sesekali, virus yang 
ditularkan ke spesies lain dan mungkin akan menyebabkan wabah bagi unggas di suatu kawasan tertentu atau menimbulkan pandemi influenza bagi manusia. Diantara tiga jenis influenza, Virus-virus type A adalah pathogen yang paling mematikan bagi manusia dan menyebabkan penyakit yang paling parah. Virus influenza A dapat dibagi menjadi beberapa serotype yang berbeda berdasarkan respon antibody terhadap virus ini. Serotypeserotype yang telah dikonfirmasi pada manusia, dikenal sebagai pandemi pembawa kematian adalah:

- H1N1 yang menyebabkan flu Spanyol tahun 1918, dan flu babi tahun 2009.

- H2N2 yang menyebabkan Flu Asia di tahun 1957

- H3N2 yang menyebabkan Flu di Hong Kong 1968

- H5N1, (Flu Burung) sebuah ancaman pandemi merupakan flu musiman 2007-2008

- H7N7, yang memiliki potensi zoonotic yang tidak biasa

- H1N2, endemik pada manusia dan babi

- $\mathrm{H} 9 \mathrm{~N} 2$

- $\mathrm{H} 7 \mathrm{~N} 2$

- $\mathrm{H} 7 \mathrm{~N} 3$

- H10N7

\subsubsection{Influenza virus B}

Genus ini memiliki satu spesies, Virus influenza B. Influenza B hampir seluruhnya menginfeksi manusia dan sangat sedikit menginfeksi dibandingkan influenza A. Satusatunya binatang yang diketahui rentan terhadap infeksi influenza B adalah singa laut dan ferret. Kemampuan bermutasi jenis influenza ini 2-3 kali lebih rendah dibandingkan tipe A, sehingga memiliki tingkat keragaman genetik yang rendah yaitu hanya terdapat satu serotype influenza B. Sebagai akibatnya, antigennya pun kurang beragam, imunitas untuk influenza B biasanya diperoleh manusia pada usia dini. Namun, bukan berarti influenza B tidak bisa lagi bermutasi.

\subsubsection{Influenza virus $C$}

Genus ini memiliki satu spesies, virus influenza $C$ yang menginfeksi manusia, anjing dan babi, kadang-kadang menyebabkan sakit parah dan epidemik (wabah) pada tingkat lokal. Influenza $\mathrm{C}$ sangat sedikit dibandingkan dengan jenis lainnya dan biasanya menyebabkan penyakit ringan pada anakanak.

\subsection{Multimedia}

Sebelumnya multimedia hanya mencakup pada text dan suara saja, namun sekarang multimedia telah berkembang pesat . Dengan adanya komputer dan televisi, kita dapat menikmati multimedia secara langsung dan menarik minat banyak orang. Bahkan multimedia semakin berkembang seperti sekarang ini dengan adanya internet.

Dengan berkembangnya teknologi dari display mode berkualitas tinggi, yang mendukung warna yang lebih dan resolusi yang lebih tinggi, grafik komputer dan gambar 
telah berkembang secara signifikan dan merupakan bagian dari aplikasi multimedia. Aplikasi Multimedia telah secara substansial mempengaruhi pendidikan. Multimedia memberikan guru sebuah kesempatan untuk mendemostrasikan dan menvisualisasikan materi pelajaran dengan lebih jelas dan komprehensif. Dan hal itu mempengaruhi gaya belajar mereka.

\section{Pembahasan}

Dari kedua artikel yang ditemukan dan telah ditelaah oleh penulis, tidak ada yang benar-benar sesuai seperti yang penulis harapkan, namun kedua artikel tersebut masih relevan terhadap apa yang penulis cari.

Studi Dewi et al, merupakan telaah sistematik yang membandingkan berbagai artikel. Dari hasil telaah diketahui bahwa belum ada penelitian efek vaksinasi influenza dalam mencegah terjadinya asma eksaserbasi akut pada dewasa akibat infeksi influenza yang didapat dari lingkungan. Keterbatasan metodologi dalam penelitian yang digunakan dalam telaah sistematik tersebut, yakni jumlah sampel yang sedikit; vaksinasi influenza yang dilakukan pada saat infeksi virus saluran nafas atas banyak terjadi, sehingga dapat menyebabkan efek gejala dan eksaserbasi asma yang timbul segera setelah vaksinasi.

Studi Suyanto et al, merupakan pengoprasian aplikasi berbasis flash. Dari hasil telaah diketahui Media pembelajaran ini dinilai dapat membantu menambah wawasan mengenai virus influenza.

\section{Kesimpulan}

Berdasarkan telaah kritis yang telah dilakukan terhadap dua studi yang ada, dapat ditarik kesimpulan bahwa vaksinasi influenza tidak berpengaruh signifikan terhadap pencegahan asma eksaserbasi akut usia dewasa. Namun secara umum, telah diketahui bahwa pemberian vaksin influenza dapat mengurangi keparahan gejala infeksi yang terjadi. Media pembelajaran berjalan dengan cukup lancar, hampir secara keseluruhan fitur berjalan dengan cukup baik. Media pembelajaran ini dinilai dapat membantu menambah wawasan mengenai virus influenza.

\section{Daftar Pustaka}

Suyanto, W. S., Liliana, L., \& Purba, K. R. (2016). Pembuatan Media Pembelajaran Virus Influenza Berbasis Flash. Jurnal Infra, 4(2), 6-11.

Dewi, N. Q., \& Nelwan, E. J. Efektivitas Vaksinasi Influenza dalam Mencegah Asma Eksaserbasi Akut pada Pasien Dewasa.

Puspita, Ika. 2010. Jadi Dokter untuk Diri Sendiri. Yogyakarta. Mizan 
